\title{
ASSESSING AND MAPPING IRRIGATION POTENTIAL IN THE ABBAY RIVER BASIN, ETHIOPIA
}

\author{
Yimere Abay*, Assefa Engdawork \\ College of Environment and Development Studies, Addis Ababa University, Ethiopia \\ *E-mail: yimabay@gmail.com
}

\begin{abstract}
Population growth and increasing food demand coupled with frequent droughts and famine have brought Ethiopia's agricultural growth to a crossroads. The Abbay River basin has untapped potential for irrigation and hydropower development. Numerous models and studies have suggested various irrigation schemes but have failed to precisely identify the irrigation potential or the cropping patterns and water withdrawal requirements of the basin. Investing in irrigation could provide a solution to meet the growing demands for food and development in Ethiopia. Using Mike Hydro model, our research goal was to map and assess the potential irrigation areas and water requirements for the entire Abbay River basin. Ethiopia's total potential irrigation area is estimated to be 7.5 million hectares (ha), and our study estimated that the potential irrigation area in the Abbay River basin is 738183 ha, which is higher than that of the Abbay Master Plan estimation of 526,000 ha. The average irrigation efficiency in the basin was calculated to be $50 \%$, and the cropping pattern ranged from 1 to 7 crops per year, and we found that maize, cotton, and sugarcane covered the highest proportions of the irrigation areas $(22 \%, 16 \%$, and $13 \%$, respectively). We categorized the regions within the basin into six irrigation schemes and found that nearly all irrigation schemes required more water between December and March. The Megech, Beles, Abbay at Kessie, and Tis Abbay regions required notably more irrigation water than the others, and we estimated the total Abbay basin's annual irrigation water requirement is 9 Billion Cubic Meters (BCM). Accordingly, our research suggests that the annual irrigation water requirement will increase significantly in the future. Thus, given the anticipated seasonal and interannual water flow variability due to climate change, our study suggests that more storage dams should be constructed to control water variability and satisfy irrigation water requirements in the basin.
\end{abstract}

\section{KEY WORDS}

Irrigation, Abbay River Basin (Upper Blue Nile), cropping patterns, intensity, water requirements, potential irrigation.

Ethiopia is endowed with abundant water resources. Most rainfall in Ethiopia occurs during summer, between June and September. Precipitation varies both spatially and temporally, and approximately $80 \%$ of precipitation occurs during the summer season (July to October). As calculated on the basis of Ethiopia's surface area and grid-based average annual rainfall, Ethiopia obtains 980 billion cubic meters (BCMs) of rainfall each year [1]. Ethiopia contains 12 major river basins; the annual streamflow from those river basins is approximately $122 \mathrm{BCMs}$, and the Abbay River basin accounts for $45 \%$ of this annual water flow. The groundwater potential is estimated to be 40 BCMs [1, 2]. The total irrigation potential from those water resources is 7.5 million hectares (ha), with a hydropower potential of $45000 \mathrm{MW}$. Rugged mountains and lowlands are features of Ethiopia's topography, which are $99.3 \%$ terrestrial areas and $0.7 \%$ water bodies [1].

Although Ethiopia has abundant water resources, due to its growing population and climate variability, the amount of available water per person is currently less than $1000 \mathrm{~m} 3$ per person; Ethiopia is therefore classified as being in water poverty. In 1990, the amount of water per person in Ethiopia was 2620 m3; in 2005, this number decreased to $1707 \mathrm{~m} 3$ per person. However, the population increased in 1990 and 2005, to 47 million and 73 million, respectively. Furthermore, due to spatial variation, lack of water storage, and rainfall 
variability, the water deficit is growing, and farmers do not obtain sufficient water to cultivate crops more than once per year [3]. Moreover, frequent droughts have led to crop failures and food shortages. Hence, efficient and appropriate irrigation utilization is critical to reduce the impacts of recurrent drought and alleviate food shortages. Agriculture contributes $40 \%$ to the GDP of Ethiopia and employs $85 \%$ of Ethiopian workers; therefore, agriculture needs to be modernized through the application and utilization of irrigation [4].

The population of Ethiopia has grown at an average of $2.5 \%$ annually since the $1960 \mathrm{~s}$ [5]. It grew from 22 million in 1960 to 117 million in 2021. In other words, since the 1960s, the population has doubled three times; in 1987, 2011, and 2021, the population was 44 million, 89 million, and 117 million, respectively $[5,6]$. Approximately 56 million people in Ethiopia are of working age. In 2014, the population of the Abbay River basin was estimated at $28,590,000$, and it has been projected to reach 40,000,000 in 2050 [7].

Agriculture is the primary income source for Ethiopia's economy. It accounts for $40 \%$ of the economy's total value added and $45 \%$ of export earnings, and it employs $75 \%$ of the formal labor force [8]. In addition to population pressure, periodically, the sector suffers from devastating droughts and famines. The most infamous droughts occurred from 1973 to1974 and from 1983 to 1985 [9].

In addition, productivity in Ethiopia is low and reliant on cropland expansion. Ethiopia's agricultural productivity is linked to changes in the amount of land used for cultivation. When production increased in the 2000s, there was also a rise in land under cultivation for crops. Accordingly, from 2003 to 2015, cropland cultivation and expansion increased by five million ha. Ethiopia's total cultivated area was estimated to be 16.4 million ha [5]. Hence, between 2003 and 2015, the amount of crop cultivation land increased by $50 \%$. This increase in cropland expansion poses the sustainability of the policy and warranted the need to increase crop production through irrigation intensification. Cropland expansion through deforestation and degradation not only increases the cost of farming but also promotes greenhouse gas (GHG) emissions, as "more than $85 \%$ of Ethiopia's GHG emissions came from the agricultural and forestry sectors" [10]. The utilization of irrigation will be an effective mechanism to increase crop production per unit of land and reduce cropland expansion, thereby reducing GHG emissions and meeting food demands.

Overview of Irrigation in Ethiopia. Irrigation is an artificial process in which water is diverted from rivers or pumped underground and utilized for agricultural production purposes. Due to climate change impacts, the area of drylands will most likely increase in the future, and available freshwater will most likely decrease. In other words, by 2050, the amount of available arable land is likely to decrease as the population continues to increase [17]. Freshwater availability will decrease, resulting in a shortage of fresh water supply for the increasing population [17, 18]. From 1961 to 2018, the global arable land ratio decreased from 0.361 to 0.184 ha per person; within a similar period, Ethiopia's arable land ratio decreased from 0.485 to 0.148 ha per person. In 2021, the world population will reach $7,772,850,805$ (7.8 billion) with average annual growth rates of $1.0 \%$; Ethiopia's population is estimated to reach $110,871,031$ in 2021 , with an average annual growth of $2.50 \%$ [19].

Irrigation has been practiced in Ethiopia for many years, although it is unclear when it began. It was not considered the major driving force of Ethiopia's ancient civilizations, such as the Aksum civilization (in the first millennium AD) [20]. While Aksumite engineers and architecture left impressive footprints with regard to their stone quarrying and masonry achievements, hardly any documents show that their civilization implemented intensive irrigation. Therefore, unlike those of other sub-Saharan countries, Ethiopia's ancient civilization most likely depended on rain-fed agriculture.

Irrigation was introduced in Ethiopia in the 1950s, in collaboration with Dutch. It was first introduced in the Awash Valley to produce commercial crops, namely, sugarcane [21]. Nevertheless, its expansion since then has been negligible. In 2002, the Irrigation Development Program (IDP) of the Ethiopian government projected an increase in the nationwide irrigation area by 274000 ha in its 15-year plan (from 2002 to 2016) [22]. Accordingly, the IDP planned 274000 ha of irrigation to be added to the existing irrigation area of 197000 ha. Later, Ethiopia's comprehensive and agriculture-led development plan, 
the Growth and Transformation Plan I (GTP I, from 2010/11-2014/15), planned to construct irrigation facilities for 658,340 ha of farmland but completed construction for only 283,408 ha [23]. In the subsequent GTP II (from 2014/15-2019/2020), the government planned to expand the national irrigated area from the 2014/15 baseline of 2.34 million ha to 4143000 ha in 2019/20 [24]. The performance of GTP II was below the implementation target. In the Ten-Year Perspective Development Plan (2020- 2030), the Ministry of Water, Irrigation and Energy (MoWIE) estimated the country's potentially irrigable land to be 7.5 million ha and provided plans to expand irrigation facilities accordingly [1]. The current potential irrigation estimate is much higher than what was projected in the 2002 IDP plan and in GTPs I and II. In Ethiopia, irrigation projects are categorized by their size. An irrigation project larger than 3 000 ha is referred to as large-scale irrigation (LSI); a project between 200 and 3,000 ha is medium-scale irrigation (MSI); and a project below 200 ha is small-scale irrigation (SSI) [22]. SSI projects are controlled by the Ministry of Agriculture and Livestock Development (MoALD), and MSI and LSI are the responsibility of MoWIE.

Ethiopia's actual irrigation utilization estimates vary among different studies. According to Hagos et al., Ethiopia utilizes/irrigates $18 \%$ of its potential irrigated area [25], while Arsano and Tamrat argue that Ethiopia utilizes only 5 or $6 \%$ of its potential irrigated area [26]. Irrigation has made only a small contribution to the economic development of the country; it contributes $9 \%$ to the agricultural GDP and 3.7\% to the overall GDP. These contributions are projected to increase to $12 \%$ and $4 \%$, respectively, in the future [25].

Irrigation Potential Assessments. Various groups have studied the irrigation potential in Ethiopia and the Abbay River basin at different times. In 1964, Lahmeyer [27] and the U.S. Bureau of Reclamation extensively studied the irrigation potential in Ethiopia and published their study findings [28]. The Water \& Power Consultancy Services Ltd (WAPCO) also conducted overall irrigation potential assessments in 1990 [29]. Similarly, the World Bank (WB) in 1973 [30], the International Food and Agricultural Organization (FAO) in 1987 [31], and the Ministry of Agriculture and Natural Resource Development (MoANRD) in 1986 [30] performed related studies. The WB estimate of irrigation potential ranged from 1.0 to 1.5 million ha, that of FAO was 2.8 million ha [30], and that of MoANRD was 2.3 million ha [32]. WAPCO's estimate of 3.5 million ha was the highest estimate of all [29].

The Eastern Nile Technical Regional Office (ENTRO) [33] suggested that potential irrigation in the Abbay River basin could reach 978000 ha; WAPCO [29] estimated 1001000 ha, and MoWIE [34] estimated 815981 ha. However, this study estimated a total of 738,183 ha of irrigation potential in six irrigation nodes. Nevertheless, it is essential to note that it is difficult to precisely determine the available irrigation potential due to data and information limitations. In particular, accounting for small-scale irrigation systems operated by individual farmers is very challenging.

Table 1 - Estimates of Irrigation Potential in the Abbay River Basin from various studies

\begin{tabular}{|l|l|l|l|l|l|}
\hline Studies conducted by & MoWIE & WAPCO 1990 & ENTRO & Abbay Master Plan & Our study \\
\hline Estimated ha & 815,581 ha & $1,001,000$ ha & 978,000 ha & 526,000 ha & 738,183 ha \\
\hline
\end{tabular}

The Abbay Master Plan identified approximately 2.5 million ha of potentially irrigable area in Ethiopia and 526000 ha in the Abbay River basin [35]. Of these Abbay River basin irrigation estimations, the Beles subbasin accounts for $28 \%$ of the potential irrigation area, Lake Tana accounts for $23 \%$, Didessa accounts for $13 \%$, Northwest accounts for $11 \%$, and the others account for $25 \%$ of the potential irrigation area [7). The Master Plan also identified 93 different irrigation schemes [34] with 526,000 ha available for irrigation, and recently the Ministry of Water Irrigation and Electricity (MOWIE) identified 560 potential irrigation sites with 815,581 ha available for irrigation. The irrigation water requirements for the schemes were expected to be fulfilled through water transfers and diversions, storage, and pumping. For example, the irrigation water requirement for the Beles subbasin is supposed to be fulfilled through water transfers and diversions at Lake Tana.

The benefits of irrigation include increasing production, fostering economic growth, creating employment opportunities and reducing production vulnerabilities. Similarly, our 
findings categorized the irrigation nodes into six schemes, and the irrigation types were dominated by surface irrigation. Surface irrigation is the primary type of irrigation in Ethiopia, though sprinkler irrigation is practiced to a limited extent in Fincha [36].

Given Ethiopia's relatively Ethiopia has abundant water resources, researchers have identified various potential and actual irrigation practices. For instance, studies conducted by Awlachew et al. [45] and Hagos et al. [46] found actual irrigated areas of 197000 ha (compared with a 3.7 million ha estimate) and 626,116 ha (compared with a 3.5 million ha estimate), respectively. Due to the absence of standardized research and auditing systems, potential irrigation estimations and water requirements have been inconsistent.

Nevertheless, today, the country's net irrigation requirement is 1,035 million cubic meters (MCM) with a potential withdrawal requirement of 2,018 MCM [46]. Furthermore, the actual withdrawal is $1,501 \mathrm{MCM}$, and the unmet demand is $401 \mathrm{MCM}$. Ethiopia's net irrigation requirement is less than those of Egypt and Sudan. Presently, all of the Nile basin countries have developed a plan to expand irrigation in the river basin. Therefore, the Nile River basin's total net irrigation demand is estimated to reach 60.9 BCM [37].

Table 2 - Current Irrigation Water Requirements for Ethiopia, Sudan and Egypt (Source: NBI) [37]

\begin{tabular}{|c|c|c|c|c|}
\hline Country & $\begin{array}{c}\text { Net irrigation requirement } \\
(\mathrm{MCM})\end{array}$ & $\begin{array}{c}\text { Withdrawal requirement } \\
(\mathrm{MCM})\end{array}$ & $\begin{array}{c}\text { Actual withdrawal } \\
(\mathrm{MCM})\end{array}$ & $\begin{array}{c}\text { Unmet demand } \\
(\mathrm{MCM})\end{array}$ \\
\hline Ethiopia & 1,035 & 2,018 & 1,501 & 402 \\
\hline Egypt & 49,185 & 68,077 & 66,060 & 430 \\
\hline Sudan & 10,242 & 13,961 & 13,923 & 38 \\
\hline
\end{tabular}

Table 3 - Ethiopia's Irrigation Water Requirements (Source NBI) [37]

\begin{tabular}{|c|c|c|c|c|c|c|}
\hline \multicolumn{3}{|c|}{ Irrigation scheme } & $\begin{array}{c}\text { Net irrigation } \\
\text { requirement } \\
(\mathrm{MCM})\end{array}$ & $\begin{array}{l}\text { Withdrawal } \\
\text { requirement } \\
(\mathrm{MCM})\end{array}$ & $\begin{array}{c}\text { Actual } \\
\text { withdrawal } \\
(\mathrm{MCM})\end{array}$ & $\begin{array}{c}\text { Unmet } \\
\text { demand } \\
(\mathrm{MCM})\end{array}$ \\
\hline \multicolumn{3}{|c|}{ Alwero Lb Ababa } & 117.25 & 239.29 & 108.28 & 131.01 \\
\hline \multicolumn{3}{|c|}{ Tis Abbay (SSI) } & 246.15 & 502.43 & 309.86 & 134.74 \\
\hline \multicolumn{3}{|c|}{ Lake Tana (SSI) } & 174.77 & 356.66 & 257.57 & 69.37 \\
\hline \multicolumn{3}{|c|}{ Koga } & 80.45 & 164.19 & 110.11 & 37.86 \\
\hline \multicolumn{3}{|c|}{ Abbay Kessie (SSI) } & 228.55 & 466.43 & 428.79 & 26.35 \\
\hline \multicolumn{3}{|c|}{ Fincha } & 149.96 & 230.35 & 230.30 & 0.07 \\
\hline Amerti-Nesh & 38.38 & 58.95 & 55.97 & \multicolumn{2}{|c|}{2.78} & \\
\hline Total & 1035.50 & 2018.21 & 1500.88 & \multicolumn{2}{|c|}{402.16} & \\
\hline
\end{tabular}

The irrigation water requirement for the six irrigation schemes above is currently 2018.21 MCM. The unmet demand is negligible. However, in our study, the total existing and planned irrigation in the Abbay River Basin is estimated to be 783,138 ha, which will increase the total irrigation water requirement to approximately $9 \mathrm{BCM}$. Based on the Ten Years Perspective Development Plan, Ethiopia's projected time to develop the Abbay river basin's potential irrigation area is 2040 .

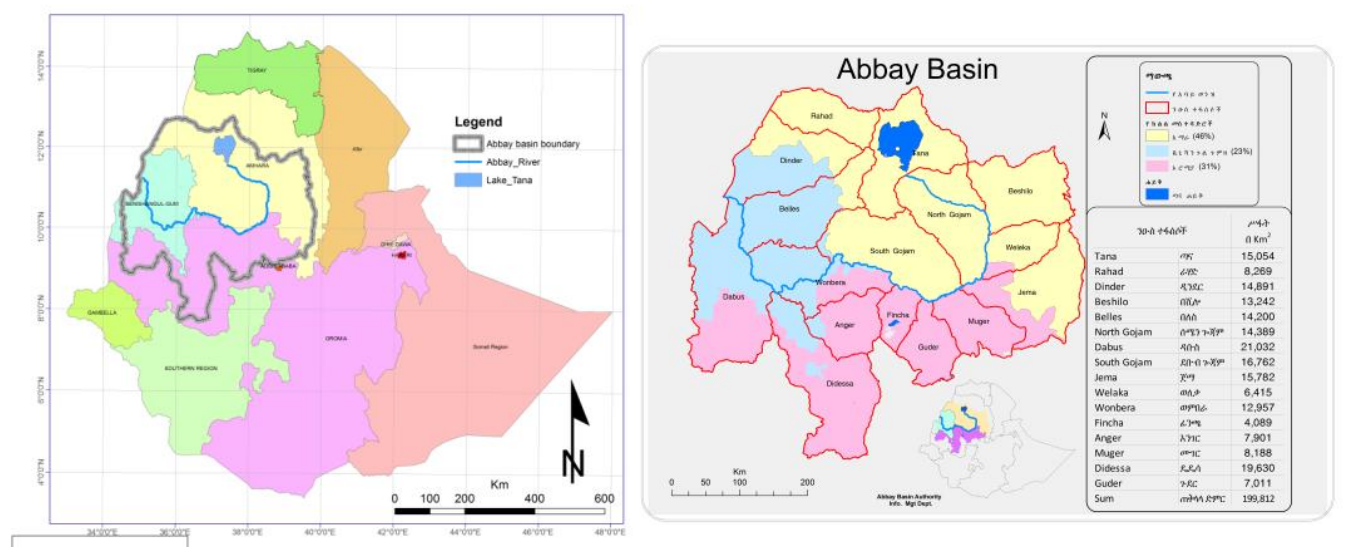

Figure 1 - Abbay Basin Area 
As it shown in Figure 1, the Abbay Basin is the largest basin in Ethiopia, and it is located in northwestern Ethiopia between 7040 ' $\mathrm{N}$ and 12051' $\mathrm{N}$ latitude and $34025^{\prime} \mathrm{E}$ and $39049^{\prime}$ E longitude. The basin occupies $200,000 \mathrm{~km} 2$ of area and makes up $20 \%$ of the country's territory [7]. It is the largest tributary of the Nile River system, contributing $56 \mathrm{m3}$ of water per year. The Abbay River passes through three Ethiopian regional governments before it joins the White Nile in Sudan, near Khartoum. Amhara, Oromia, and BeneshangulGumuz are the regional governments within the Abbay River basin in Ethiopia. Within Ethiopia, the Abbay basin covers $40 \%$ of the Oromia regional jurisdiction, $60 \%$ of the Amhara jurisdiction, and $95 \%$ of the Beneshangul-Gumuz jurisdiction [7]. All three states are characterized by subsistence farming with crop cultivations and livestock husbandry. From 90- $95 \%$ of the cultivated cop comes from rainfed agriculture.

Ethiopia's highlands extend from 1500 to 4260 masl and exhibit various slopes throughout different parts of the country [49]. In the lowlands of the Abbay River basin, such as in Dinder and Rahad, the slope is less than 7\%; in the eastern part of the basin, the slope exceeds $25 \%$. In short, $85 \%$ of the Abbay Basin has less than a $30 \%$ slope, $12 \%$ of the area has a slope between 30 and $60 \%$, and $3 \%$ of the basin has a slope of $3 \%$ or above [7].

In this study, we examined the existing and estimated irrigation nodes in the Abbay River basin because the expansion of irrigation is imperative. In the last few years, Ethiopia has expanded its croplands by five million ha or $50 \%$ of its cropland, which equals the size of Kenyan. Thus, it is only a matter of time before irrigation in the Abbay River basin expands [5]. Most of the planned irrigation requirements are expected to be met using water storage, diversion, and transfers. Therefore, collaborations among riparian states are necessary to mitigate possible river flow reductions and meet the growing demand for water now and in the future.

Therefore, this study's primary foci are assessing and describing the potential for irrigation and evaluating the existing irrigation water demand based upon the currently deployed technology. Second, Ethiopia's government explicitly expressed a goal of increasing irrigation from the current potential of 5.2 million ha to 7.5 million ha in its ten-year perspective development plan (2020-2030). Moreover, most of the available potential irrigation area is in the Abbay River basin [5, 30]. Thus, we estimated the planned irrigation water demands and cropping patterns in this area. When estimating the current and future irrigation water demands, we assumed that the current irrigation technology would remain in use for some time to come. We also assumed that the population is rapidly increasing and that the growing food demand will pressure the government of Ethiopia to increase and utilize the available potential irrigation area. Our potential irrigation assumptions are based in reality, and they include the cropping patterns in each irrigation node and the types of plants to be grown as well as the irrigation efficiency and intensity.

\section{MATERIALS AND METHODS OF RESEARCH}

In this study, we used Mike Hydro model, developed by the Danish Hydrologic Institute (DHI) [38]. It is a comprehensive water resource management and planning model. Mike Hydro is also used as the NBI decision support system (DSS) for the Nile River Basin, making it a comprehensive and valid tool for our study [39]. It is a versatile decision support tool for water resource planners, decision-makers, climate scientists, and researchers. The MIKE modeling system simplifies climate scenario analysis and visualization. Using the Mike Hydro modeling package and Allen et al, [40], we estimated the irrigation potential and water requirements in the study area. When assessing water losses, the literature and published values of irrigation efficiencies were properly used and have been. Most Ethiopian irrigation systems apply surface irrigation, and no leaching losses were calculated; rather, the total irrigation water usage is expected to balance the leaching losses. There are a wide variety of different irrigation methods that can be used to estimate irrigation efficiency [41, 42, 43, 44]; however, in this study, the surface and sprinkler methods were used to estimate the irrigation efficiencies, as $98 \%$ of Ethiopian irrigation types are surface irrigation, and $2 \%$ are sprinkler irrigation. 
The application and conveyance efficiency largely depend on the soil type and represent the efficiency of water use. The conveyance efficiency differs among canals and depends on the permeability, length, and quality of the canals. The soil types that the canals pass through also affect the irrigation conveyance efficiency. The application efficiency refers to the efficiency of the use of the water applied for irrigation.

The available irrigation canals in the Abbay River basin are fully lined; therefore, the water loss through seepage is assumed to be zero. Irrigation efficiency below $30 \%$ is not acceptable, while efficiency values at $50-60 \%$ or higher are generally referred to as good. Accordingly, the suggested values used in our methods of determining the conveyance efficiencies are: for the surface irrigation method, an application efficiency between 50 and $70 \%$ with a conveyance efficiency between 40 and $70 \%$; and for the sprinkler irrigation method, an application efficiency between 55 and $75 \%$ with a conveyance efficiency between 60 and $90 \%$ [41-44].

Table 4 - Assumed Values Taken from FAO No. 56

\begin{tabular}{|c|c|c|c|c|}
\hline \multirow{2}{*}{ Canal length } & \multicolumn{3}{|c|}{$\begin{array}{c}\text { Earthen canals } \\
\text { Soil type }\end{array}$} \\
\cline { 2 - 4 } & Sand & Loam & Clay & \\
\hline$>2000 \mathrm{~m}$ & $60 \%$ & $70 \%$ & $80 \%$ & $95 \%$ \\
\hline $200-2000 \mathrm{~m}$ & $70 \%$ & $75 \%$ & $85 \%$ & $95 \%$ \\
\hline$<200 \mathrm{~m}$ & $80 \%$ & $85 \%$ & $90 \%$ & $95 \%$ \\
\hline
\end{tabular}

Data on irrigation methods and technologies were gathered from ENTRO [42], the Abbay Basin Atlas at the Bahirdar Office [7], GTP I \& II [23, 24], the Ethiopian Statistics Agency (CSA) [6], the FAO Drainage and Irrigation guidelines [41 -44] and Bart et al. [46], FAO Aquastat (47), and MOIE (48). Crop pattern data were also collected from the Eastern Nile Irrigation and Drainage study, which is available as a Cooperative Regional Assessment document.

\section{RESULTS AND DISCUSSION}

Due to the lack of complete data and information on irrigations, our results presented here are based on assumptions and simulates based on available data and information. Mike Hydro used irrigation water requirements and scenarios to give the Abbay basin water resource planners and decision-makers evidence to plan and act.

In the irrigated area of the Abbay River basin, we observed that greater crop intensification options are available. The cropping intensity is, therefore, expressed as the ratio of the gross cropped area to that of the net sown area. In the irrigation areas, productivity can be increased through irrigation intensification. This will help to slow the expansion of cultivated croplands and therefore slow the increase in GHG emissions.

Generally, within the study area, the water withdrawal requirement is much higher than the crop water requirement. The highest water requirements were determined for Megech, Abbay at Kessie, Lower Beles, and Tis Abbay. The highest irrigation water requirement also occurred during the spring season, particularly from March to April. Each irrigation scheme had different cropping patterns, equipped and cropped areas, intensities, and water requirements. The cropping pattern indicates whether crops are planted once or twice a year. The existing irrigation schemes refer to the currently cultivated areas, and the planned schemes refer to potential irrigation areas. The equipped area refers to the irrigation area that is equipped for irrigation, and the cropped area refers to the actually cropped portion of the irrigation area. In other words, the cropped area is the area covered by crops at least once in a given year.

Irrigation potential and existing areas in the Abbay River basin. The group I irrigation scheme includes the Abbay at Kessie, Gilgel Abbay, Koga, Middle Birr, Lake Tana, and Tis Abbay nodes. The total irrigation area in group I is 243766 ha, of which 178,766 ha are a planned irrigation scheme, and 65000 ha are irrigated at 50\% efficiency and once-a-year 
cropping patterns. The irrigation efficiencies and cropping patterns in group I are the lowest of all irrigation groups in this study, and the group I irrigation scheme is an underutilized irrigation scheme.

The group II irrigation scheme includes the Lower Beles, Lower Dinder, Rahad, and Upper Dinder nodes. In group II, there is no actual irrigation, and all irrigation values provided are estimates. The estimated available irrigable land is 206600 ha. The typical cropping pattern involves two crops in a year with $50 \%$ irrigation efficiency. The largest estimated irrigation area within this group is available in Lower Beles, while the smallest estimated irrigation area is in Upper Dinder. Beles has the most significant potential irrigation area in the Abbay basin, as it includes $28 \%$ of the basin's total potential irrigation.

The group III irrigation scheme includes the Amerti-Neshe, Fincha, and Upper Beles nodes. The cropping pattern is three crops per year, with an irrigation efficiency of $50 \%$. There is no existing irrigation in Upper Beles, but Amerti-Neshe and Fincha have irrigation. The smallest irrigation area is in Fincha, and the largest is in Upper Beles. The total irrigation area in group III is 73190 ha, with an estimated irrigation area of 58,390 ha and existing irrigation of 14800 ha.

There are no existing irrigation schemes in group IV. This group includes the Anger, Lower Dabus, Lower Didessa, Lower Guder, Shegoli, Upper Dabus, and Upper Didessa nodes. The available, total irrigable area is 163,015 ha. The irrigation efficiency is $50 \%$, and the cropping pattern is four crops per year.

Table 5 - Abbay River Basin Irrigation Area by Scheme (Existing and Potential)

\begin{tabular}{|c|c|c|c|c|c|c|}
\hline Index & Node & Area (ha) & Cropping & Efficiency & Existing & Planned \\
\hline \multicolumn{7}{|c|}{ Group 1} \\
\hline 1 & Abbay at Kessie & 58141 & 1 & 50 & 21500 & 36641 \\
\hline 2 & Gilgel Abbay & 17244 & 1 & 50 & & 17244 \\
\hline 3 & Koga & 14500 & 1 & 50 & 7000 & 7500 \\
\hline 4 & Middle Birr & 4670 & 1 & 50 & & 4670 \\
\hline 5 & Lake Tana & 104551 & 1 & 50 & 15000 & 89551 \\
\hline 6 & Tis Abbay & 44660 & 1 & 50 & 21500 & 23160 \\
\hline \multicolumn{7}{|c|}{ Group 2} \\
\hline 7 & Lower Beles & 85000 & 2 & 50 & & 85000 \\
\hline 8 & Lower Dinder & 50000 & 2 & 50 & & 50000 \\
\hline 9 & Rahad & 55000 & 2 & 50 & & 55000 \\
\hline 10 & Upper Dinder & 16600 & 2 & 50 & & 16600 \\
\hline \multicolumn{7}{|c|}{ Group 3} \\
\hline 11 & Amerti-Neshe & 11870 & 3 & 50 & 7200 & 4670 \\
\hline 12 & Fincha & 7600 & 3 & 50 & 7600 & 0 \\
\hline 13 & Upper Beles & 53720 & 3 & 50 & & 53720 \\
\hline \multicolumn{7}{|c|}{ Group 4} \\
\hline 14 & Anger & 35106 & 4 & 50 & & 35106 \\
\hline 15 & Lower Dabus & 15400 & 4 & 50 & & 15400 \\
\hline 16 & Lower Didessa & 31671 & 4 & 50 & & 31671 \\
\hline 17 & Lower Guder & 21015 & 4 & 50 & & 21015 \\
\hline 18 & Shegoli & 10604 & 4 & 50 & & 10604 \\
\hline 19 & Upper Dabus & 4081 & 4 & 50 & & 4081 \\
\hline 20 & Upper Didessa & 45138 & 4 & 50 & & 45138 \\
\hline \multicolumn{7}{|c|}{ Group 5} \\
\hline 21 & Muger & 7444 & 5 & 50 & & 7444 \\
\hline 22 & Upper Guder & 9819 & 5 & 50 & & 9819 \\
\hline \multicolumn{7}{|c|}{ Group 6} \\
\hline 23 & Beko Abo & 14549 & 7 & 50 & & 14549 \\
\hline 24 & Karadobe & 6120 & 7 & 50 & & 6120 \\
\hline \multirow[t]{2}{*}{25} & Mendaya & 13681 & 7 & 50 & & 13681 \\
\hline & Total & & & & 79,800 & $658,384.00$ \\
\hline
\end{tabular}

The group $V$ irrigation scheme includes only two irrigation nodes: Muger and Upper Guder. As in the group IV irrigation scheme, there is no existing irrigation in this group, and 
all irrigation data are estimated. However, the cropping pattern is more intense than that in group IV. Group V includes 17,263, ha with 50\% irrigation efficiency and five crops per year.

The final irrigation scheme, group VI, includes the Bako Abo, Karadobe, and Mendaya irrigation nodes, and there is no existing irrigation in this scheme. A total of 34350 ha of irrigable land is estimated to be utilized in this group. The cropping patterns were the highest intensity of those in all irrigation schemes, with seven crops per year and an efficiency of $165 \%$. The irrigation nodes in group VI are nodes for both irrigation and hydropower. Therefore, this irrigation scheme is more likely to be useful and beneficial in two aspects, i.e., food production and hydropower generation.

Finally, of the total irrigation area, group I makes up 33\%, group II makes up $28 \%$, group III makes up 10\%, group IV makes up $22 \%$, group makes up V $2 \%$, and group VI makes up 5\%. Group I, the largest group, has the lowest-intensity cropping patterns. Therefore, the government needs to modernize irrigation schemes and crop patterns to increase their benefits.

Share of the irrigation area occupied by each irrigation scheme. As per the data we collected and analyzed, the total potential irrigation area in the Abbay River basin is 738183 ha. Of these, 79800 ha are currently irrigated, while 658,384 ha represent untapped potential irrigation. The largest area of irrigation potential is in group I (Abbay at Kessie, Gilgel Abbay, Koga, Middle Birr, Lake Tana, and Tis Abbay), and the second largest is in group II (Upper Beles, Lower Dinder, Rahad, and Upper Dinder); the smallest area of irrigation potential is in group V (Muger and Upper Guder), as shown in Figure 2.

In all six irrigation schemes, irrigation water requirements are highest during the spring season, particularly from March to April. Accordingly, the Megech, Upper Beles, Abbay at Kessie, and Tis Abbay irrigation schemes are expected to require more water than the others, as shown in Figure 3 and 4.

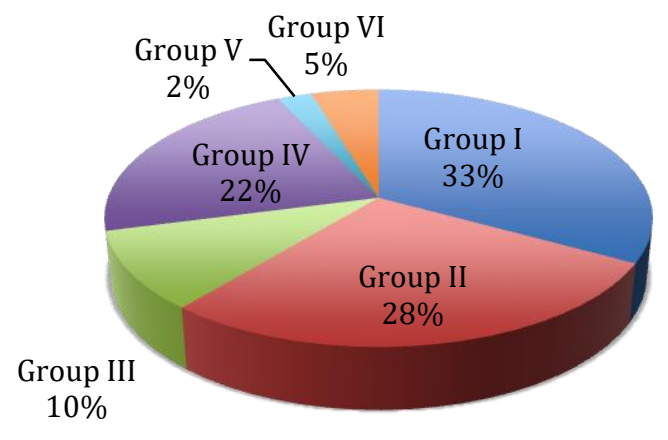

Figure 2 - Share of the total irrigation area, 738183 ha

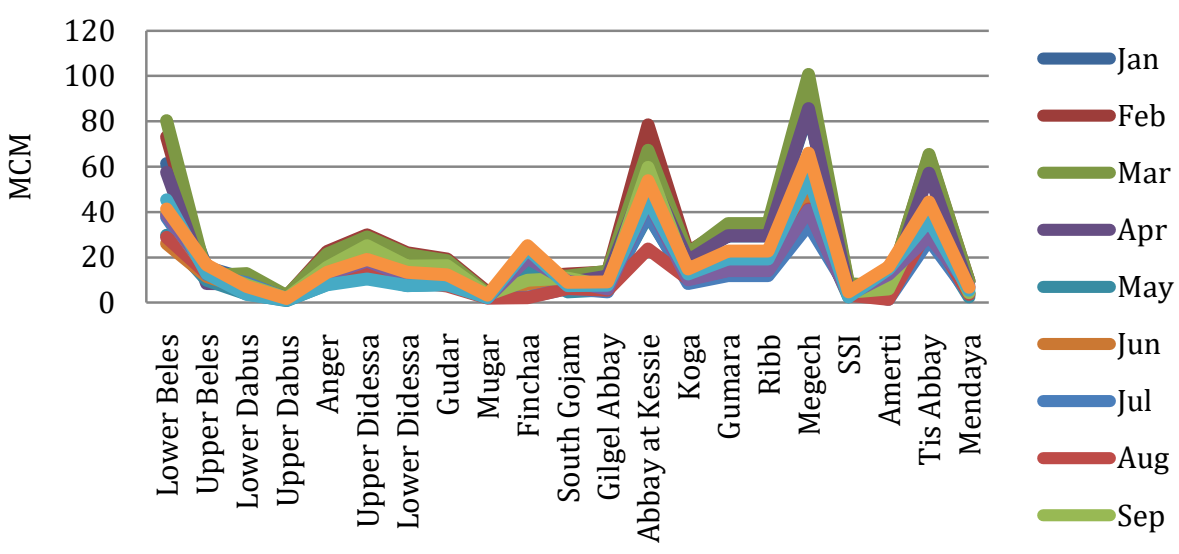

Figure 3 - Monthly irrigation water requirements per irrigation nodes 


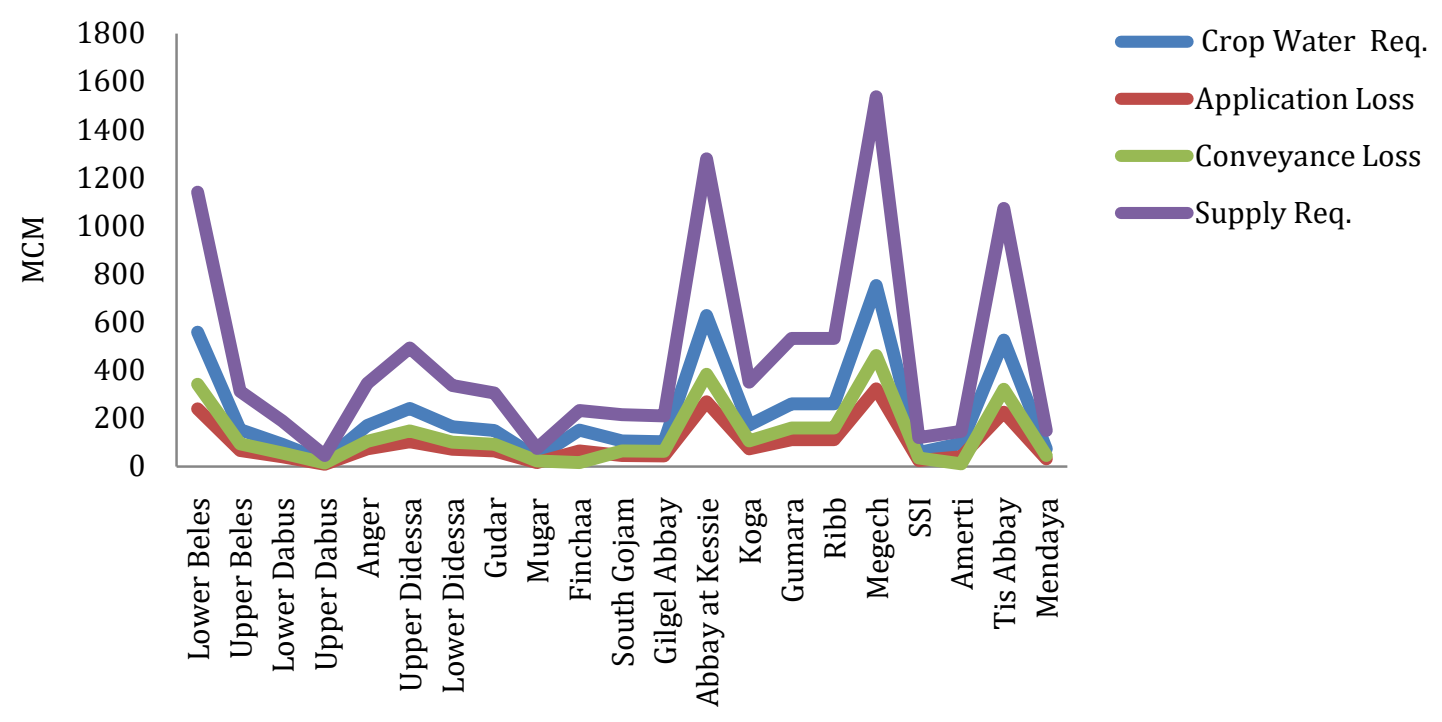

Figure 4 - Annual irrigation water requirements per irrigation nodes

When all irrigation schemes are fully functional and operational, the annual irrigation water requirement for the Abbay River basin will reach 9 BCMs. Megech, Abbay at Kessie, Upper Beles, and Tis Abbay will have the highest water requirements. The primary rainy season occurs between June and October, while the highest water demand for irrigation occurs between December and March (see Appendix I). This highlights the importance of developing water storage in the Abbay River basin. Water storage is critical for controlling seasonal and interannual water variability and satisfying irrigation water demands. This finding is consistent with previous studies recommending the construction of storage dams to regulate the increased seasonal and interannual water flow variability and store the additional water flows caused by climate change. Additional studies of the enhanced water flow variability in the river basin are imperative to inform an increase in the water storage capacity and the full utilization of stored water to maintain mean annual flows and the use of water for both irrigation and hydropower development.

\section{CONCLUSION}

The purposes of this study are to assess and map the existing and potential irrigation areas in the Abbay River basin and to estimate the irrigation water requirements in the basin. The study finds 738,183 ha of potential irrigation area and a $9 \mathrm{BCM}$ annual water requirement, and the Blue Nile water flow at the Ethiopia-Sudan border will decrees proportionally. The cropping patterns in the basin are estimated to range from 1 to 7 crops per year, with irrigation efficiency of $50 \%$ and up to $165 \%$ crop intensity. The utilization of irrigation schemes could help Ethiopia achieve its goals of food security and economic development.

Therefore, irrigation is critical to reducing poverty, ensuring food security and improving the economy in Ethiopia; this is particularly true in rural communities, where most of the population lives in abject poverty. Additionally, irrigation is critical for reducing GHG emissions from slash-and-burn methods of cropland expansion. The effective utilization of irrigation can increase agricultural production per unit area without expanding rain-fed croplands or requiring intensive chemical application, which in turn could be sources of GHG emissions. In this context, GTP II projected that irrigation would reduce GHG emissions from crop production by 25.97 million metric tons by $2019 / 2020$ and by 77.9 million metric tons by 2030.

Finally, the source of the Abbay River is in Ethiopia, and the Abbay River contributes 56 BCM annually to the Nile River. As per the Harmon Doctrine, the 2030 SDGs, and the 
1977 UN Watercourse Convention, which state that each riparian country is entitled to an equitable and reasonable share of transboundary water resources, Ethiopia shall utilize its area of the river basin to irrigate the currently estimated irrigation area as well as additional areas. However, since WB OP 7.50 restricts the mobilization of finance from Bretton Wood and other multilateral institutions, Ethiopia needs to strengthen its technical and financial capabilities to construct further irrigation and hydropower projects to achieve the country's interests and meet the needs of its people. Additionally, it is vital to negotiate win-win solutions for this region. Negotiation issues could include water storage, mutually beneficial food and energy production, and flood control as well as the development of climate-proof transboundary water treaties and the mutual abrogation of both the 1929 and 1959 Nile Water Agreements. Given Ethiopia's high altitude, the availability of deep gorges in the country, and the subsequent low evaporation potential, Ethiopia is a suitable environment for the construction of additional reservoir dams $[49,50]$.

Appendix I - Estimation of crop water requirements and irrigation supply requirements (BCM/year)

\begin{tabular}{|c|c|c|c|c|c|c|c|c|c|c|c|c|c|c|c|c|c|}
\hline ID & Irrigation Scheme & Jan & Feb & Mar & Apr & May & Jun & Jul & Aug & Sep & Oct & Nov & Dec & $\begin{array}{l}\text { Crop } \\
\text { Water } \\
\text { Req }\end{array}$ & $\begin{array}{l}\text { Application } \\
\text { Losses }\end{array}$ & $\begin{array}{l}\text { Conveyance } \\
\text { Loss }\end{array}$ & $\begin{array}{l}\text { Supply } \\
\text { Req }\end{array}$ \\
\hline 1 & Lower Beles & 61.3 & 73.1 & 80.4 & 57.5 & 29.7 & 26.0 & 37.6 & 28.8 & 39.3 & 38.7 & 45.3 & 41.3 & 559.0 & 239.6 & 342.3 & 1140.9 \\
\hline 2 & Upper Beles & 15.6 & 11.2 & 11.9 & 8.5 & 9.8 & 11.5 & 12.4 & 12.8 & 14.4 & 15.0 & 12.9 & 16.7 & 152.8 & 65.5 & 93.5 & 311.8 \\
\hline 3 & Lower Dabus & 10.5 & 11.5 & 12.9 & 8.2 & 3.8 & 5.8 & 8.8 & 7.2 & 7.8 & 5.0 & 3.7 & 7.1 & 92.3 & 39.6 & 56.5 & 188.4 \\
\hline 4 & Upper Dabus & 2.7 & 2.9 & 3.0 & 1.9 & 0.9 & 1.5 & 1.8 & 1.6 & 2.0 & 1.3 & 1.0 & 1.8 & 22.4 & 9.6 & 13.7 & 45.8 \\
\hline 5 & Anger & 19.8 & 22.5 & 21.5 & 14.1 & 8.0 & 11.3 & 12.5 & 10.8 & 15.5 & 12.2 & 7.8 & 13.4 & 169.5 & 72.6 & 103.8 & 345.9 \\
\hline 6 & Upper Didessa & 26.2 & 29.9 & 29.0 & 18.2 & 11.9 & 16.8 & 20.6 & 15.4 & 25.1 & 18.4 & 10.5 & 19.1 & 241.0 & 103.3 & 147.6 & 491.8 \\
\hline 7 & Lower Didessa & 19.5 & 22.0 & 21.3 & 12.8 & 7.5 & 10.9 & 13.0 & 9.6 & 16.2 & 11.5 & 7.5 & 13.4 & 165.2 & 70.8 & 101.1 & 337.1 \\
\hline 8 & Gudar & 16.9 & 19.2 & 18.5 & 13.1 & 8.1 & 10.2 & 7.9 & 7.4 & 16.4 & 12.0 & 7.9 & 12.3 & 150.0 & 64.3 & 91.8 & 306.1 \\
\hline 9 & Mugar & 4.1 & 4.7 & 4.0 & 3.1 & 2.7 & 2.9 & 2.1 & 2.0 & 3.4 & 2.2 & 2.1 & 3.3 & 36.7 & 15.7 & 22.5 & 74.9 \\
\hline 10 & Fincha & 11.9 & 11.3 & 11.4 & 10.4 & 15.0 & 8.2 & 2.3 & 2.2 & 9.9 & 19.7 & 23.7 & 25.2 & 151.1 & 64.8 & 16.2 & 232.1 \\
\hline 11 & S Gojam & 12.1 & 12.7 & 11.7 & 8.7 & 4.7 & 6.4 & 6.3 & 6.2 & 10.9 & 9.5 & 7.5 & 9.0 & 105.7 & 45.3 & 64.7 & 215.7 \\
\hline 12 & Gilgel Abbay & 11.9 & 13.5 & 13.9 & 11.8 & 5.7 & 5.9 & 4.7 & 5.4 & 7.4 & 6.0 & 7.7 & 9.1 & 102.9 & 44.1 & 63.0 & 210.1 \\
\hline 13 & Abbay at Kessie & 66.2 & 78.5 & 67.2 & 57.3 & 38.6 & 51.8 & 39.5 & 23.7 & 59.8 & 45.1 & 45.3 & 53.8 & 626.7 & 268.6 & 383.7 & 1278.9 \\
\hline 14 & Koga & 19.9 & 22.4 & 21.7 & 18.5 & 9.7 & 10.6 & 8.5 & 10.4 & 13.0 & 10.0 & 12.6 & 14.8 & 172.1 & 73.8 & 105.4 & 351.2 \\
\hline 15 & Gumara & 29.4 & 33.3 & 34.9 & 29.6 & 14.7 & 15.9 & 11.9 & 14.3 & 20.4 & 14.1 & 19.2 & 22.8 & 260.5 & 111.7 & 159.5 & 531.7 \\
\hline 16 & Ribb & 29.4 & 33.3 & 34.9 & 29.6 & 14.7 & 15.9 & 11.9 & 14.3 & 20.4 & 14.1 & 19.2 & 22.8 & 260.5 & 111.7 & 159.5 & 531.7 \\
\hline 17 & Megech & 84.9 & 96.2 & 100.7 & 85.7 & 42.5 & 46.0 & 34.3 & 41.4 & 59.1 & 40.7 & 55.4 & 66.0 & 752.9 & 322.7 & 461.0 & 1536.6 \\
\hline 18 & Small Scale & 7.1 & 7.8 & 8.5 & 5.2 & 2.5 & 3.5 & 5.2 & 3.2 & 4.5 & 3.5 & 2.6 & 4.8 & 58.4 & 25.0 & 35.8 & 119.2 \\
\hline 19 & Amerti & 7.5 & 7.1 & 7.1 & 6.5 & 9.5 & 5.2 & 1.5 & 1.4 & 6.1 & 12.4 & 14.9 & 15.8 & 95.1 & 40.8 & 10.2 & 146.1 \\
\hline 20 & Tis Abbay & 57.9 & 64.7 & 65.5 & 57.2 & 31.3 & 36.1 & 27.8 & 32.8 & 42.1 & 29.4 & 36.3 & 44.4 & 525.4 & 225.2 & 321.7 & 1072.3 \\
\hline 21 & Mendaya & 9.5 & 9.5 & 9.5 & 6.6 & 2.6 & 4.0 & 3.9 & 3.7 & 4.4 & 7.3 & 5.4 & 6.8 & 73.3 & 31.4 & 44.9 & 149.6 \\
\hline \multicolumn{17}{|c|}{ Total } & 9618.0 \\
\hline
\end{tabular}

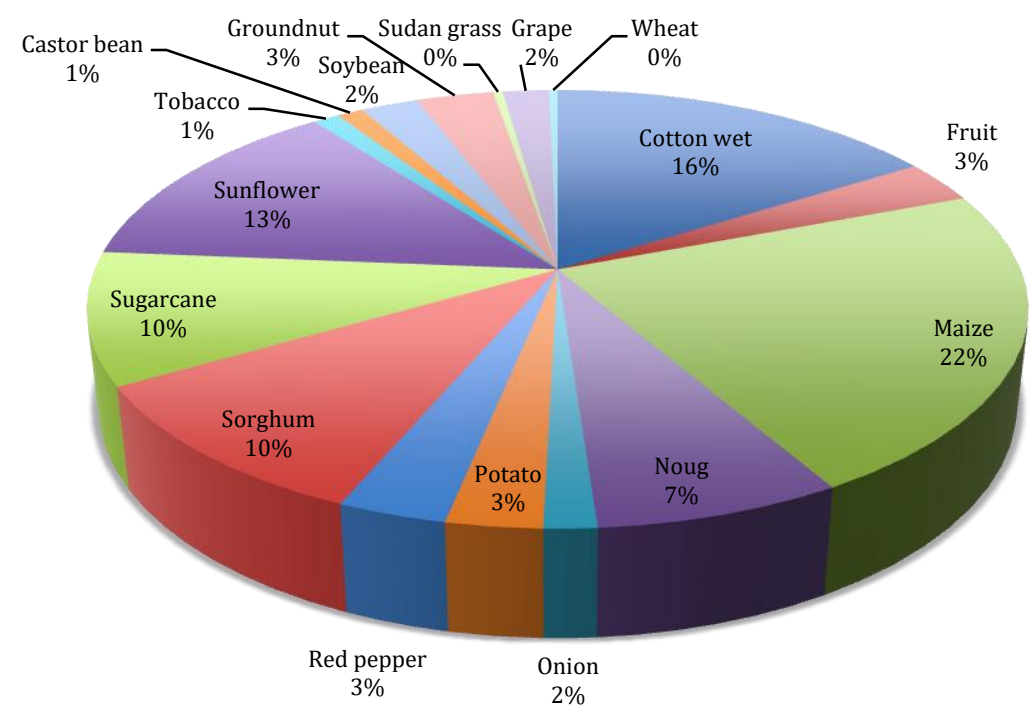

Appendix II - Crop Distribution 


\section{AUTHORS' CONTRIBUTION}

Both authors contributed equally to the development of this article. Abay Yimere conceptualized methodological and theoretical formalism and performed the analysis. Engdawork Assefa supervised the study. Both authors discussed the results and contributed to the final version of the manuscript.

\section{ACKNOWLEDGEMENTS}

The authors would like to thank Yohannes Gebretsadik from Nile Basin Initiative (NBI), Professor Kenneth Marc Strzepek, and Nardos Amdework, for their constructive comments, conversations, and feedback.

\section{CONFLICTS OF INTEREST}

The authors declare that they have no known competing financial interests or personal relationships that could have appeared to influence the work reported in this paper.

\section{REFERENCES}

1. Awulachew, S. B., Erkossa, T., \& Namara, R. E. (2010.) Irrigation potential in Ethiopia. Constraints and Opportunities for Enhancing the System; International Water Management Institute: Addis Ababa, Ethiopia

2. Federal Democratic Republic Ethiopia (FDRE) (2021). Planning and Development Commission, Ten Years Development Perspective (2020- 2030), Addis Ababa, Ethiopia

3. Awulachew, S. B., Yilma, A. D., Loulseged, M., Loiskandl, W., Ayana, M. \& Alamirew, T. (2007). Water Resources and Irrigation Development in Ethiopia. Working Paper 123. International Water Management Institute, Colombo, Sri Lanka.

4. Tawfik Amer, Rawia M . ( 2015). Revisiting hydro -hegemony from a benefit sharing perspective: the case of the Grand Ethiopian Renaissance Dam , Discussion Paper, No. 5/2015, ISBN 978-3-88985-669-2, Deutsches Institut für Entwicklungspolitik (DIE), Bonn

5. United States Agency for International Development (USAID) (2018). Ethiopia Development Trend Assessment, Ethiopia Performance and Evolution Services (EPMES), Addis Ababa, p1-203, unpublished.

6. Central Statistical Agency (CSA). Ethiopian Population Projection 2019. Available online https://www.statsethiopia.gov.et/wp content/uploads/2019/11/Projected-Population-ofEthiopia-20112019.pdf (accessed on 9 June 2020)

7. Abbay Basin Atlas (2018). Abbay Basin Basic Information; Amhara Regional Government, Bahir Dar, Ethiopia

8. Teshome, M. (2014). Population growth and cultivated land in Rural Ethiopia: land use dynamics, access, farm size, and fragmentation. Resources and Environment 4(3), 148161.

9. Kumar, G. (1987). WIDER Working Papers. Ethiopian Famines 1973-1985: A case Study. WP 26.

10. Federal Democratic Republic Ethiopia (FDRE) (2010). Environmental Protection Agency (EPA. Climate Resilience Growth (CRGE), Addis Ababa, Ethiopia

11. Nina V Fedoroff, V. N. (2015). Food in a Future of 10 billion. Fedoroff Agric \& Food Secur 4 (11) DOI 10.1186/s40066-015-0031-7

12. World Bank (WB): Online https://data.worldbank.org/indicator/AG.LND.ARBL.HA.PC (accessed on 05 June 2020)

13. United States Census: Available online https://www.census.gov/datatools/demo/idb/\#/country?YR_ANIM=2021\&menu=countryViz\&COUNTRY_YEAR=2021 (accessed on 05 June 2020) 
14. Sulas, F.; Madella, M.; French, C. (2009). State formation and water resources management in the Horn of Africa: the Aksumite Kingdom of the northern Ethiopian highlands. World Archaeology, 41, 2-15

15. Gebremedhin, G. H.; Kasa, K.A. (2015). Irrigation in Ethiopia: A review. Academia Journal of Agricultural Research. Academia Publishing, 3(10): 264-269. DOI: 10.15413/ajar.2015.0141

16. Federal Democratic Republic of Ethiopia (FDRE) (2002). Ministry of Water Resources (MoWR) Water Sector Development Programme 2002-2016, Irrigation Development Program, Main report. MoWR, Addis Ababa, Ethiopia, p142

17. Federal Democratic Republic of Ethiopia (FDRE) (2010). Ministry of Finance and Economic Development, Growth and Transformation Plan 2010/11-2014/15. Addis Ababa, Ethiopia

18. Federal Democratic Republic of Ethiopia (FDRE) (2014). Ministry of Finance and Economic Development, Growth and Transformation Plan 2014/15-2019/2020, Addis Ababa, Ethiopia

19. Hagos F, Makombe G, Namara RE, Awulachew SB (2009). Importance of Irrigated Agriculture to the Ethiopian Economy: Capturing the Direct Net Benefits of Irrigation. Colombo, Sri Lanka. Int. Water Manage. Institute. IWMI Research Report 37:128.

20. Arsano, Y., \& Tamrat, I. (2005). Ethiopia and the Eastern Nile Basin. Aquatic Science , 67 , 15-27

21. Lahmeyer Consulting Engineers (1964). Gilgel Abay Scheme, Imperial Ethiopian Government. Ministry of Public Works, Addis Ababa

22. United States Bureau of Reclamation (USBR) (1964). Land and Water Resources of the Blue Nile Basin, Main Report. United States Dept. of Interior Bureau of Reclamation, Washington, DC, USA

23. Water \& Power Consultancy Services Ltd. (WAPCOS) (1990).. Preliminary Water Resources Development Master Plan for Ethiopia, Final Report, prepared for EVDSA. Addis Ababa, Ethiopia.

24. Awlachew, S. B,; Demissie, S. S.; Hagos, F.; Erkossa, T.; Peden, D. (2012). Water management intervention analysis in the Nile Basin. In: The Nile River Basin Water, Agriculture, Governance and Livelihoods Awlachew, S. B., Smahktin, V., Molden D., Peden, D., eds). Routledge, New York, USA 2012

25. Food and Agriculture Organization of the United Nations (FAO) (2000). Water and Agriculture in the Nile Basin. Land and Water Development Division Rome, Italy.

26. Mulata, G. A.; Moges, A. S.(2020). The impacts of Upper Blue Nile Dams construction on agricultural water availability of Sudan; IWA Publishing, Water Practice \& Technology 15 (2). doi: 10.2166/wpt.2020.031

27. Eastern Nile Technical Regional Office (ENTRO) (2006). Water Atlas of the Blue Nile Sub-Basin, Draft Report. Eastern Nile Technical Regional Office (ENTRO), Ethiopia

28. Bureau Central d'Etudes pour les Equipements d'Outre-Mer (BCEOM) (1998). Abbay river basin integrated development master plan, section II, volume $\mathrm{V}$-water resources development, part 1- 2 irrigation and drainage. Ministry of Water Resources, Addis Ababa,

29. ABBAY river basin integrated development master Plan project (1998). Addis Ababa, Ethiopia

30. Ministry of Agriculture (MoA) (2011a). Natural Resources Management Directorates. Small-Scale Irrigation Situation Analysis and Capacity Needs Assessment, Addis Ababa, Ethiopia.

31. Nile Basin Initiative (NBI) (2019). Technical Report III, Entebbe, Uganda, Unpublished.

32. Danish Hydraulic Institute (DHI) (2008). DHI product suite, Set of manuals. Danish Hydraulic Institute, Denmark

33. Progea, S R L.(2003). Deliverable 10 Report On Models, Tools And DSS For Water Management 
34. Allen, R. G.; Pereira, L. S.; Raes, D.; Smith, M. (1998). Crop evapotranspiration: guidelines for computing crop water requirements, Irrigation and Drainage Paper 56. United Nations FAO, Rome, p300

35. Howell, T. A. (2003). Irrigation efficiency, Encyclopedia of water science. Marcel Dekker, New York, 467-472.

36. Brouwer, C.; Prins, K.; Heibloem, M. (1989). Irrigation water management: irrigation scheduling, Training manual, 4.

37. Lankford, B. (2012). Fictions, fractions, factorials and fractures; on the framing of irrigation efficiency. Agr. Water Manage. 108, 27-38

38. Mende, M. D. (2015). Agricultural Economist, FAO Investment Centre. Food and Agriculture Organization of the United Nations, Rome, 1-70, p25

39. Eastern Nile Irrigation and Drainage Studies 9ENTRO-IDS) (2009). Cooperative Regional Assessment, Analyses Report; ENTRO, Entebbe, Uganda

40. Bart, J., Balikuddembe, S., Thuo, S., Schuette, P., (2011). Food for Thought: Demand for agricultural produce in the Nile Basin for 2030: four scenarios. Food and Agriculture Organization of the United Nations, Rome.

41. AQUASTAT - FAO's Global Information System on Water and Agriculture

42. Federal Democratic Republic of Ethiopia (FDRE) (2020). Ministry of Water Irrigation and Electricity, Irrigation Bulletin, Addis Ababa

43. Conway, D. (2017). Future Nile River flows. Nature Climate Change, 7

44. Siam, S. M.; Eltahir, A.B. E. (2017). Climate change enhances interannual variability of the Nile river flow. Nature climate change DOI: 10.1038/NCLIMATE3273 